\title{
Research Article \\ Performance of oyster mushroom (Pleurotus ostreatus) grown on different fingermillet husk substrates
}

\author{
Priyanka Sanjel $^{1 *}$, Ram Kumar Shrestha ${ }^{1}$ and Jiban Shrestha ${ }^{2}$ \\ ${ }^{1}$ Institute of Agriculture and Animal Science, TU, Lamjung Campus, Lamjung, Nepal \\ ${ }^{2}$ Nepal Agricultural Research Council, National Plant Breeding and Genetics Research Centre, \\ Khumaltar, Lalitpur, Nepal \\ *Correspondence: preeyankasanjel@gmail.com \\ *ORCID: https://orcid.org/0000-0003-3824-752X \\ Received: October 07, 2020; Accepted: December 17, 2020; Published: January 01, 2021
}

(C) Copyright: Sanjel et al. (2021). (c) (1) 9 This work is licensed under a Creative Commons Attribution-Non Commercial
4.0International License.

\begin{abstract}
Substrate type is one of the major factors affecting the growth and yield of oyster mushroom (Pleurotus ostreatus). Five substrates; Finger millet husk, Fingermillet husk + Molasses, Fingermillet husk + Rice bran, Fingermillet husk + Wheat bran, Fingermillet husk +Mustard oilseed cake, were evaluated for growth and productivity of oyster mushroom. The experiment was conducted in a completely randomized design with each treatment replicated seven times. Additives were added on finger millet husk @ 5\% of its dry weight. Standard cultivation practice was followed with steam sterilization and spawning was done in poly bags containing $2.5 \mathrm{~kg}$ of wet substrate. Data were collected on time taken for full spawn run, fresh mushroom yield, biological efficiency and cropping duration upto three flushes. Molasses took the least duration (16.86 days) for full spawn run which was found to be statistically at par with wheat bran(17.13 days) and rice bran(17.75 days) whereas control treatment took the longest duration (21.62 days). Rice bran produced the highest fresh mushroom yield (793.04g/bag) with highest biological efficiency (137.92\%), which was statistically at par with control, molasses and wheat bran. Similarly, rice bran had least cropping duration (66.62 days) followed by control (67.88 days), molasses (69.14 days), wheat bran (70.12 days) and mustard oilseed cake (73.86 days). The lowest fresh yield (521.84 g/bag) with lowest biological efficiency (90.75\%) and the longest cropping duration (73.86 days) was observed on mustard oilseed cake supplementation. This study revealed that molasses, rice bran and wheat bran accelerated spawn run whereas mustard oilseed cake supplementation produced lowest fresh mushroom yield with least biological efficiency and highest cropping duration showing that it was ineffective for increasing yield and productivity of oyster mushroom.
\end{abstract}

Keywords: Additives, Biological efficiency, Pleurotus ostreatus, Substrate.

Correct citation: Sanjel, P., Shrestha, R. K., \& Shrestha, J. (2021). Performance of oyster mushroom (Pleurotus ostreatus) grown on different fingermillet husk substrates. Journal of Agriculture and Natural Resources, 4(1), 291-300.

DOI: https://doi.org/10.3126/janr.v4i1.33370

\section{INTRODUCTION}

The mushrooms of genus Pleurotus ranks second in the world mushroom market after Agaricus bisporus (Sanchez, 2009). Oyster mushroom (Pleurotus ostreatus) is an edible mushroom having excellent taste and flavor. It belongs to the class Basidiomycetes, subclass Hollobasidiomycetidae and order Agaricales. Oyster mushrooms having a considerable economic, medicinal and nutritional value are most commonly and commercially cultivated on 

industrial and forest wastes can be efficiently utilized. Ninety kinds of wastes have been proven to be useful for oyster mushroom cultivation (Zhang et al., 2001) that serves for malnutrition alleviation in the third world countries. The use of a supportive substrate to enhance the growth and the development of sporophores is a fundamental requirement for the production process of mushrooms (Hayes, 1981). A good substrate should be rich in nutrients, have good aeration and water holding capacity (Wightman, 1999) and have high lignocellulosic content (Nandi \& Mukherjee, 2006). Agricultural substrates are utilized for cultivation of oyster mushroom. The growth and yield of oyster mushroom differ with various substrates as reported by Dhakal et al. (2020). More than 200 different types of substrate have been reported to support the effective growth of Pleurotus spp. based on a worldwide survey done on oyster mushroom substrates (Chang, 1999). Protein and nitrogen rich substances that are used to supplement the substrates to boost their growth and production potentials are known as additives. Most additives are organic materials like wheat bran, rice bran, flours of maize, rice, cowpea, horse gram, mustard oilseed cake, molasses etc. Despite the significance of additives, Nepali farmers are generally not aware about its role in mushroom cultivation. In addition to this various locally available organic substrates like finger millet husk, maize straw, rice and wheat straw etc. are either being burnt or fed to the livestock. Thus, this research was carried out with an objective to evaluate the role of additives on the yield performance of Pleurotus ostreatus cultivated on fingermillet husk. This research aims to evaluate the influence of additives on time taken for full spawn run, total fresh mushroom yield and biological efficiency of $P$. ostreatus cultivated on fingermillet husk. It also aims to compare the cropping duration of $P$. ostreatus under different supplementation that will help to decrease the existing protein gap of our country through enhanced mushroom production.

\section{MATERIALS AND METHODS}

\section{Location of the experiment site}

The research was conducted at Institute of Agriculture and Animal Sciences (IAAS), Lamjung campus on 23 Dec 2017.

\section{Collection of materials}

Finger millet husk was obtained from the millet growing farmers and mustard oilseed cake, rice bran, wheat bran and molasses were obtained from the traders in vicinity of IAAS, Lamjung and they were all stored at the room temperature.

\section{Preparation of base materials}

The substrate was soaked in the water for 12 hours prior to pasteurization. Then the pasteurization of substrate was achieved in plastic sac bags using metal drums by steaming in boiling water for about 45-60 minutes. After pasteurization the substrate was spread on the sterilized floor and it was cooled. The moisture content of the substrate was adjusted to around $65 \%$ during the filling of substrate. Palm test was also performed for determination of moisture content.

\section{Additives preparation}

The additives were sterilized in an autoclave at a temperature of $121^{\circ} \mathrm{C}$ for 15 minutes except molasses that didn't needed sterilization and were used @ $5 \%$ of the dry weight of substrate. 
Journal of Agriculture and Natural Resources (2021) 4(1): 291-300

ISSN: 2661-6270 (Print), ISSN: 2661-6289 (Online)

DOI: https://doi.org/10.3126/janr.v4i1.33370

\section{Design of the experiment}

The experiment was set up using complete randomized design (CRD) with five treatments each replicated seven times. The experimental design was presented as below:

T1 (Control): Fingermillet husk (No additives)

T2: Fingermillet husk + Molasses

T3: Fingermillet husk + Rice bran

T4: Fingermillet husk + Wheat bran

T5: Fingermillet husk +Mustard oilseed cake

\section{Filling of poly-bags}

$575 \mathrm{~g}$ of dry weight of substrate which accounted for nearly $2.5 \mathrm{~kg}$ of the wet weight was filled in poly bags by making a base layer of about 4 inches in thickness and the additive was kept on the central portion of the layer. Spawn was then spread uniformly on the outer rings in circular pattern. Similarly the $2^{\text {nd }}$ and $3^{\text {rd }}$ layers were prepared. The $4^{\text {th }}$ layer was also prepared but in the fourth layer no additive was used and instead of additive the spawn was uniformly spread all over the top. About $62.5 \mathrm{~g}$ of spawn was used for one poly- bag which accounted for $10 \%$ of the dry weight of substrate. Then the poly-bag was tightly tied on the top with a band so as to avoid the microbial contamination and the tagging was done.

\section{Spawn running}

The inoculated substrates were then kept in a dark room at temperature of about $25^{\circ}-30^{\circ} \mathrm{C}$ and $65-75 \%$ relative humidity. The perforation of the bags was done by making a small hole of about $10 \mathrm{~mm}$ to allow proper aeration inside the bag. The poly-bags were kept in a bench so as to prevent the clump formation of the substrate. The darkness of the room was maintained by covering the windows and roof by black plastic. Spawn run (mycelia extension) was observed regularly until a whitish mycelia growth (colonization) had spread to both lower and upper sides of the bags from the inoculated zone. The tied bags were opened after the full spawn run was seen. Ventilation was allowed for the circulation of fresh air and entry of diffused sunlight. Irrigation was done two times a day in order to maintain relative humidity around $80-90 \%$. Gunny bags wetted with water were kept on the floor to maintain the room temperature and humidity. Mushroom was allowed to fruit under the ambient temperatures. Insect management was done by sticky traps for flies and Nuvan was also used. $2 \%$ Carbendazim solution, a broad spectrum fungicide was used by dipping the cotton pieces in the solution and spot application was done for control of Trichoderma spp, Mucor spp and Penicillium spp. The waiting period after the fungicide application was 7days.

\section{Harvesting of fruiting bodies}

The fruiting bodies were harvested when most of them matured completely which was usually 4-5 days after pinhead formation. A light twist on the lower portion of the stipe was given for the harvest of the fruiting bodies. The substrate was incubated under the same conditions after each harvest for second and third flushes. Mushrooms from different treatments were kept separately for fresh weight measurement.

\section{Fresh Weight Determination}

For fresh weight determination irrigation was stopped 24 hours prior to harvest. Freshly harvested mushroom from all the supplements were weighed using an electronic weighing balance. After the weight determination the data were taken on the stipe length and upward and side diameter of the pileus using the conventional methods. Biological efficiency was calculated as: Biological efficiency $=$ (yield of fresh mushroom in gram / total weight of dry substrate in gram) $\times 100$. 


\section{Statistical Analysis}

Data thus obtained were entered on the excel sheet and then it was subjected to analysis of variance (ANOVA) while the means were separated with Duncan Multiple Range Test (DMRT) at the 5\% level of significance (Gomez \& Gomez, 1984; Shrestha, 2019). SPSS version 16.0 (IBM Corp, 2007) was used for the overall analysis of the data collected.

\section{RESULTS AND DISCUSSION}

\section{Effect of substrates on timing for full spawn run}

Time for full spawn run is the total duration taken from spawning to complete colonization of the substrate with whitish mycelial growth. The data regarding the number of days taken for the full spawn run is shown in Table 1. From this experiment it was observed that treatments molasses supplementation, rice bran and wheat bran supplementation were statistically at par with each other. Similarly mustard oilseed cake supplementation and control were also statistically at par with each other. Molasses supplementation, rice bran and wheat bran supplementation were significantly different from control and mustard oilseed cake supplementation. The most rapid spawn running took place in treatment with molasses supplementation which took 16.86 days and control took the maximum number of days i.e. 21.62 days. The days taken for the completion of spawn run, were in agreement with the findings reported by Shah et al. (2004) and Tan (1981) where the spawn run took three weeks. The least time for full spawn run taken by substrate with molasses supplementation might be due to the nutritional properties of molasses as it contains nutrient minerals like Manganese, copper, Iron, Calcium, Potassium, Magnesium,Selenium, Vitamin B6,carbohydrates, sugar and nitrogen sources. Alemawor et al. (2009) found that Mn supplementation from molasses was found critical in improving bioconversion of cocoa pod husk by P. osteratus. Sobhan (2006) found that the highest duration to complete spawn running was found in mustard oilseed cake at $50 \%$ level which might be due to the antifungal properties of mustard oilseed cake.

Table1: Effect of additives on Time of full spawn run (TFSR) of Pleurotus ostreatus cultivated on fingermillet husk.

\begin{tabular}{cll}
\hline S.N. & \multicolumn{1}{c}{ Treatments } & TFSR(Days) \\
\hline 1 & Fingermillet husk+ Molasses & $16.86^{\mathrm{b}}$ \\
2 & Fingermillet husk+ Wheat bran & $17.13^{\mathrm{b}}$ \\
3 & Fingermillet husk+ Rice bran & $17.75^{\mathrm{b}}$ \\
4 & Fingermillet husk+ Mustard oilseed cake & $21.43^{\mathrm{a}}$ \\
5 & Fingermillet husk (Control) & $21.62^{\mathrm{a}}$ \\
\hline & Mean & 18.94 \\
& SEM & 0.41 \\
& F test & $* *$ \\
& CV\% & 13.21 \\
\hline
\end{tabular}

Note: means with the different letters in the same column are significantly different $(\mathrm{P} \leqslant 0.05)$ by Duncan's multiple range test. ** highly significant at 0.01 level of significance.

\section{Effect of substrates on fresh yield from first, second and third flush}

The data for the effect of additives on yield from first, second and third flush of $P$. ostreatus grown on finger millet husk is shown in Table 2. On harvest of first flush control gave the highest yield which is statistically at par with rice bran, wheat bran and molasses supplementation. In the second flush molasses gave the highest fresh mushroom yield which is statistically at par with rice bran, wheat bran, and control. In the third flush rice bran gave the highest yield which was statistically at par with molasses, wheat bran and control. The lowest yield was obtained from mustard oilseed cake supplementation in all the three flushes. 
Journal of Agriculture and Natural Resources (2021) 4(1): 291-300

ISSN: 2661-6270 (Print), ISSN: 2661-6289 (Online)

DOI: https://doi.org/10.3126/janr.v4i1.33370

Therefore from the crop harvested in three flushes maximum yield was obtained in first flush than second and third flushes. It might be due to the availability of maximum nutrients in substratum. This study agreed with the observation of Oei (2003) for Volvariella esculenta. This is also in agreement with the findings reported by Khan et al. (2013) where maximum yield and quality of mushroom was obtained in the first flush. Similar finding was also obtained by Hoa et al. (2015) for Pleurotus ostreatus where the yield gradually decreased after third flush.

Table 2: Effect of additives on the fresh mushroom yield from $1^{\text {st }} 2^{\text {nd }}$ and $3^{\text {rd }}$ flush of $P$. ostreatus cultivated on finger millet husk.

\begin{tabular}{lllll}
\hline SN & Treatments & \multicolumn{3}{c}{ Mushroom yield(g) per 575 g of substrate } \\
\cline { 3 - 5 } & & $1^{\text {st }}$ flush & $2^{\text {nd }}$ flush & $3^{\text {rd }}$ flush \\
\hline 1 & Fingermillet husk + Rice bran & $453.62^{\mathrm{a}}$ & $239.97^{\mathrm{a}}$ & $99.44^{\mathrm{a}}$ \\
2 & Fingermillet husk(Control) & $469^{\mathrm{a}}$ & $220.78^{\mathrm{a}}$ & $90.81^{\mathrm{a}}$ \\
3 & Fingermillet husk+ Molasses & $426.6^{\mathrm{ab}}$ & $245.27^{\mathrm{a}}$ & $91.34^{\mathrm{a}}$ \\
4 & Fingermillet husk+ Wheat bran & $437.45^{\mathrm{ab}}$ & $207.05^{\mathrm{a}}$ & $77.4^{\mathrm{a}}$ \\
5 & Fingermillet husk+ Mustard & $391.71^{\mathrm{b}}$ & $91.89^{\mathrm{b}}$ & $38.24^{\mathrm{b}}$ \\
& oilseed cake & 437.1 & & \\
\hline & Mean & 8.8 & 202.7 & 60.2 \\
& SEM & NS & 9.6 & $* .1$ \\
& F test & 12.4 & 29.5 & 27 \\
\hline
\end{tabular}

Note: means with the different letters in the same column are significantly different $(\mathrm{P} \leqslant 0.05)$ by Duncan's multiple range test. ** highly significant at 0.01 level of significance.

\section{Effect of substrates on total yield and biological efficiency}

The data for the effect of additives on total fresh mushroom yield from three flushes and biological efficiency of $P$. ostreatus cultivated on finger millet husk is shown in Table 3. The highest total fresh mushroom yield was obtained from rice bran supplementation $(793.04 \mathrm{~g} / \mathrm{bag})$ with highest biological efficiency $(137.92 \%)$ which was closely followed by control $(780.59 \mathrm{~g} / \mathrm{bag})$ with biological efficiency $(135.75 \%)$, molasses supplementation $(763.21 \mathrm{~g} / \mathrm{bag})$ with biological efficiency $(132.73 \%)$, wheat bran supplementation $(721.9 \mathrm{~g} / \mathrm{bag})$ with biological efficiency(125.54\%), whereas the lowest fresh mushroom yield was obtained from mustard oilseed cake supplementation $(521.84 \mathrm{~g} / \mathrm{bag})$ with lowest biological efficiency $(90.75 \%)$. Therefore, control, molasses supplementation, rice bran supplementation and wheat bran supplementation are statistically at par with each other for total fresh mushroom yield and biological efficiency whereas they are significantly different with mustard oilseed cake supplementation. Similar results were found by Viziteu (2004) in his research where supplementation of $P$. ostreatus with additives didn't increase the productivity significantly. The decreased yield may be due to the higher dose of supplements i.e. greater than 2-3\%. Gupta and Vijay (1991) also reported that supplementation above $2 \%$ resulted in undue heating of compost which may be the cause for reduced yield. This is supported from the results obtained by Sharma (2009) in which supplementation of 2\% wheat bran and 2\% rice bran resulted 48.1 $\%$ and $48.3 \%$ increase in yield of $P$. ostreatus respectively over the control. The lowest total yield was given by mustard oilseed cake supplementation in our research. Similar result was described by Upadhyay (2002) in which the lowest yield was recorded in the bags of $P$. ostreatus where mustard oilseed cake was added. Krupodorova and Barshteyn (2015) also found the slight growth of mushroom species on the mustard oilseed cake that contains $37 \%$ protein, $6 \%$ carbohydrate and $11 \%$ fat indicating that probably the high fat content in the cake doesn't contribute to the mushroom growth and also probably due to the limitation of the essential components. Similarly, Alam et al. (2007) observed that the biological efficiency ranged from 45.21 to $125.70 \%$ in oyster mushroom. 
Journal of Agriculture and Natural Resources (2021) 4(1): 291-300

ISSN: 2661-6270 (Print), ISSN: 2661-6289 (Online)

DOI: https://doi.org/10.3126/janr.v4i1.33370

In addition to this, the results found by Oseni et al. (2012) showed that total yield (390.9g/500g substrate) was obtained on sawdust supplemented with 5\% wheat bran over the cropping period of $P$. ostreatus which showed us that fingermillet husk is an efficient lignin degrader than sawdust as on the same percent concentration of the additives i.e. 5\% wheat bran, fingermillet husk gave the higher total fresh mushroom yield i.e. $721.90 \mathrm{~g} / 575 \mathrm{~g}$ of substrate.

Table 3: Effects of additives on total fresh mushroom yield from three flushes and biological efficiency of $\boldsymbol{P}$. ostreatus cultivated on fingermillet husk.

\begin{tabular}{llll}
\hline SN & Treatments & $\begin{array}{l}\text { Total fresh mushroom yield } \\
\text { from three flushes }\end{array}$ & $\begin{array}{l}\text { Biological } \\
\text { efficiency }\end{array}$ \\
\hline 1 & Fingermillet husk + Rice bran & $793.04^{\mathrm{a}}$ & $137.92 \%$ \\
2 & Fingermillet husk(Control) & $780.59^{\mathrm{a}}$ & $135.75 \%$ \\
3 & Fingermillet husk+ Molasses & $763.21^{\mathrm{a}}$ & $132.73 \%$ \\
4 & Fingermillet husk+ Wheat bran & $721.90^{\mathrm{a}}$ & $125.54 \%$ \\
5 & Fingermillet husk+ Mustard oilseed cake & $521.84^{\mathrm{b}}$ & $90.75 \%$ \\
\hline & Mean & 719.9 & 125.2 \\
& SEM & 21.7 & 3.7 \\
& F test & $* *$ & $* *$ \\
& CV\% & 18.6 & 18.7 \\
\hline
\end{tabular}

Note: means with the different letters in the same column are significantly different $(\mathrm{P} \leqslant 0.05)$ by Duncan's multiple range test. ** highly significant at 0.01 level of significance.

Effect of substrates on duration for first and second harvest and total cropping duration The statistical analysis of data for effect of additives on the duration for first harvest, second harvest and total cropping duration (time taken from spawning to total harvest) is shown in the Table 4. For the harvest duration of first flush the treatments were found to be significantly different. Rice bran supplementation took the least duration (37.25 days) for harvest of first flush which was found to be significantly different from control (41.37 days). Control was statistically at par with molasses supplementation (40.86 days) and wheat bran supplementation (40 days). Molasses supplementation, rice bran supplementation, wheat bran supplementation and control were found to be significantly different from mustard oilseed cake supplementation that took 44.14 days for the harvest of first flush. Thus, supplementation with mustard oilseed cake took the longest duration for the harvest of first flush. These results are similar with the results of different scientists. Heltay (1987) observed that fruit bodies appeared after 49 days of spawning of $P$. florida using different lingo cellulosic substrates like rye, barley, and wheat bran. Khan et al., (2001) examined the cultivation of oyster mushroom on different cellulosic substrates. It was observed that after spawn running pinhead formations take 7-8 days while sporocarps formed after 10-12 days.

On the statistical analysis of data for the duration of harvest of second flush it was found that rice bran supplementation took the least duration (52.88 days) which was statistically at par with wheat bran supplementation (54.38 days), control(55.25 days) and molasses supplementation (56.29 days). Molasses supplementation, rice bran supplementation, wheat bran supplementation and control were found to be significantly different from mustard oilseed cake supplementation (63.14 days) on the duration taken for the harvest of the second flush

Similarly, analysis of variance for treatment means showed that the total cropping duration differed significantly. On the statistical analysis of data for the cropping duration it was found that rice bran supplementation showed the least cropping duration (66.62 days) which was statistically at par with control (67.88 days) and molasses supplementation (69.14 days). Molasses supplementation, rice bran supplementation, wheat bran supplementation and control 
Journal of Agriculture and Natural Resources (2021) 4(1): 291-300

ISSN: 2661-6270 (Print), ISSN: 2661-6289 (Online)

DOI: https://doi.org/10.3126/janr.v4i1.33370

were found to be significantly different from mustard oilseed cake supplementation $(73.86$ days) for cropping duration. Thus, mustard oilseed cake was found to have highest cropping duration in this research.

Table 4: Effect of additives on duration for $1^{\text {st }}, 2^{\text {nd }}$ harvest and total cropping duration of $P$. ostreatus cultivated on fingermillet husk

\begin{tabular}{|c|c|c|c|c|}
\hline S.N. & Treatments & $\begin{array}{l}\text { Duration for first } \\
\text { harvest. }\end{array}$ & $\begin{array}{l}\text { Duration for } 2^{\text {nd }} \\
\text { harvest }\end{array}$ & Cropping duration. \\
\hline 1 & Fingermillet husk+ Rice bran & $37.25^{\mathrm{c}}$ & $52.88^{\mathrm{b}}$ & $66.62^{\mathrm{c}}$ \\
\hline 2 & $\begin{array}{l}\text { Fingermillet husk } \\
\text { (Control) }\end{array}$ & $41.37^{\mathrm{b}}$ & $55.25^{\mathrm{b}}$ & $67.88^{b c}$ \\
\hline 3 & Fingermillet husk+ Molasses & $40.86^{\mathrm{b}}$ & $56.29^{\mathrm{b}}$ & $69.14^{\mathrm{bc}}$ \\
\hline 4 & Fingermillet husk+ Wheat bran & $40^{\mathrm{b}}$ & $54.38^{\mathrm{b}}$ & $70.12^{\mathrm{b}}$ \\
\hline \multirow[t]{5}{*}{5} & $\begin{array}{l}\text { Fingermillet husk+ Mustard } \\
\text { oilseed cake }\end{array}$ & $44.14^{\mathrm{a}}$ & $63.14^{\mathrm{a}}$ & $73.86^{\mathrm{a}}$ \\
\hline & Mean & 40.6 & 56.2 & 69.5 \\
\hline & SEM & 0.48 & 0.77 & 0.98 \\
\hline & F test & $* *$ & $* *$ & $* *$ \\
\hline & $\mathrm{CV} \%$ & 7.3 & 8.4 & 15.4 \\
\hline
\end{tabular}

Note: means with the different letters in the same column are significantly different $(\mathrm{P} \leqslant 0.05)$ by Duncan's multiple range test. ** highly significant at 0.01 level of significance.

\section{Effect of substrates on pileus diameter and stipe length of $\boldsymbol{P}$. ostreatus}

The statistical analysis of the data for the effect of additives on average diameter of pileus and average length of stipe of $P$. ostreatus cultivated on fingermillet husk from three flushes is shown in Table 5. The average pileus diameter was found to be highest in molasses supplementation $(6.94 \mathrm{~cm})$, which was statistically at par with control $(6.82 \mathrm{~cm})$, rice bran supplementation $(6.76 \mathrm{~cm})$ and wheat bran supplementation $(6.84 \mathrm{~cm})$. The lowest pileus diameter was found in mustard oilseed cake supplementation $(6.06 \mathrm{~cm})$. Therefore, control, molasses supplementation, rice bran supplementation and wheat bran supplementation were statistically different from mustard oilseed cake supplementation in terms of average pileus diameter.The findings of the present study matches with the study of Habib et al. (2005) who found that the diameter of pileus ranged from 4.85-8.95 cm. Similarly, our results are in agreement with the findings of Fasidi et al. (2008), he reported that very good mushroom pileus were produced on substrates with rice bran (containing $1.3 \% \mathrm{~N}$ ). In addition, the size of the mushroom is dependent on substrates that were poor in cellulose, hemicelluloses and lignin which constitute physical barrier and are difficult to be broken down without the presence of lignin degrading enzymes (Jonathan \&Adeoyo, 2011).

Similarly, the highest average stipe length was found in molasses supplementation $(2.69 \mathrm{~cm})$, that was found to be statistically at par with control $(2.18 \mathrm{~cm})$, rice bran supplementation $(2.33$ $\mathrm{cm})$ and wheat bran supplementation $(2.27 \mathrm{~cm})$. The lowest stipe length was found in mustard oilseed cake supplementation $(1.41 \mathrm{~cm})$. Therefore, control, molasses supplementation, rice bran supplementation and wheat bran supplementation were found to be statistically different from mustard oilseed cake supplementation. The findings of the present study matched with the study of Sarker et al. (2007) and Habib (2005) as they reported that the stipe length of Pleurotus spp. on different substrate varied from $1.93-2.97 \mathrm{~cm}$. The trend of variation of pileus diameter was more or less similar to that of stipe length growth which is in accordance with the findings of Tajudeen et al. (2012). In contrary to our result Adenipekun (2015) found that 
Journal of Agriculture and Natural Resources (2021) 4(1): 291-300

ISSN: 2661-6270 (Print), ISSN: 2661-6289 (Online)

DOI: https://doi.org/10.3126/janr.v4i1.33370

supplementation of $P$. pulmonarius with $30 \%$ wheat bran produced the highest stipe length in rice straw and banana leaves as compared to rice bran supplementation.

Table 5: Effect of additives on average diameter of pileus and average length of stipe of $P$. ostreatus cultivated on fingermillet husk

\begin{tabular}{llll}
\hline S.N. & Treatments & $\begin{array}{l}\text { Average diameter of } \\
\text { pileus (AP) }\end{array}$ & $\begin{array}{l}\text { Average length of } \\
\text { stipe (AS) }\end{array}$ \\
\hline 1 & Fingermillet husk(control) & $6.82^{\mathrm{a}}$ & $2.18^{\mathrm{a}}$ \\
2 & Fingermillethusk+ Molasses & $6.94^{\mathrm{a}}$ & $2.69^{\mathrm{a}}$ \\
3 & Fingermillet husk+ Rice bran & $6.76^{\mathrm{a}}$ & $2.33^{\mathrm{a}}$ \\
4 & Fingermillet husk+ Wheat bran & $6.84^{\mathrm{a}}$ & $2.27^{\mathrm{a}}$ \\
5 & Fingermillet husk+ Mustard oil cake & $6.06^{\mathrm{b}}$ & $1.41^{\mathrm{b}}$ \\
\hline & Mean & 6.6 & 2.1 \\
& SEM & 0.08 & 0.13 \\
& F test & $* *$ & $* *$ \\
& CV\% & 8 & 20.6
\end{tabular}

Note: means with the different letters in the same column are significantly different $(\mathrm{P} \leqslant 0.05)$ by Duncan's multiple range test. ** highly significant at 0.01 level of significance.

\section{CONCLUSION}

Fingermillet being the fourth most important cereal crop of Nepal, the cultivation of Pleurotus in fingermillet husk helps in its utilization which would otherwise be wasted in burning and feeding animals. This study successfully demonstrated that molasses, rice bran and wheat bran were good additives for the cultivation of Pleurotus ostreatus on finger millet husk. Although these additives did not produce a significant increase in total fresh mushroom yield over control and also did not significantly decreased the cropping duration in comparison to control, they decreased the time for full spawn run. In addition to these, mustard oilseed cake was found to be the poorest performer in terms of time of full spawn run, fresh mushroom yield, biological efficiency and cropping duration which may have been resulted due to its antifungal properties. Therefore the mustard oilseed cake supplementation was not found to be suitable for $P$. ostreatus cultivated on fingermillet husk.

\section{ACKNOWLEDGEMENT}

Financially this work was supported by Institute of Agriculture and Animal Science, TU, Lamjung Campus, Lamjung, Nepal

\section{Authors' Contributions}

P. Sanjel planned, designed and conducted this experiment and wrote the initial draft of this mansucript. R. K. Shrestha helped and guided to conduct the experiment and writing this manuscript. J. Shrestha helped in data analysis and made revision of initial draft of the manuscript. All authors approved the final version of this manuscript to be published.

\section{Conflict of interest}

The author declares no conflicts of interest regarding publication of this manuscript.

\section{REFERENCES}

Alam, N., Khan, A., Hossain, M.S., Amin, S.M.R., \& Khan, L.A. (2007). Nutritional Analysis of dietary Mushroom Pleurotusflorida Eger and Pleurotussajor-caju (Fr.) Singer. Bangladesh J. Mushroom, 1(2), 1-7. 
Journal of Agriculture and Natural Resources (2021) 4(1): 291-300

ISSN: 2661-6270 (Print), ISSN: 2661-6289 (Online)

DOI: https://doi.org/10.3126/janr.v4i1.33370

Alemawor, F., Dzogbefia, V. P., Oddoye, E. O., \& Oldham, J. H. (2009). Effect of Pleurotusostreatus fermentation on cocoa pod husk composition: Influence of fermentation period and $\mathrm{Mn} 2+$ supplementation on the fermentation process. African journal of biotechnology, 8(9), 1950-1958.

Chang, S.T., \&Buswell, J.A. (1999). Ganodermalucidum (Curt.:Fr.) P. Karst. (Aphyllophoromycetidease): A mushrooming medicinal mushroom. Int. J. Med. Mushrooms, 1, 139-146.

Dhakal, P., Pokhrel, A., Bista, A., Shah, K., Acharya, B., \& Shrestha, J. (2020). Growth and yield performance of oyster mushroom (Pleurotus ostreatus) on different substrates. Agriways, 8 (2), 1-8

Fasidi, I.O., Kadiri, M., Jonathan, S.G., Adenipekun, C.O., \&Kuforiji, O.O. (2008). Cultivation of Edible Tropical Mushrooms. Pp. 29-40.

Gomez, K.A., \& Gomez, A.A. (1984). Statistical procedures for agricultural research.2nd edn. International Rice Research Institute, College, Laguna, pp. 680.

Gupta, Y., \& Vijay, B. (1991). Post composting supplementation in Agaricusbisporus under seasonal growing conditions. 13th International Congress of ISMS held at Dublin, Ireland.

Habib, M. A. (2005). Comparative study on cultivation and yield Performance of Oyster Mushroom (Pleurotusostreatus) on different substrates. Thesis, M.Sc. Department of Biotechnology, BAU, Mymensingh.

Hayes, W.A. (1981). Interrelated studies of physical, chemical and biological factors in casing soils and relationships with productivity in commercial culture of Agaricusbisporus Lange (Pilat). Mushroom Sci., 11, 103 - 129.

Heltay, I. (1987). Production of oyster mushroom on large scale with modern techniques. P.H.M. Rev. Hort., 1977.

Hoa, H. T., Wang, C. L., \& Wang, C. H. (2015). The Effects of Different Substrates on the Growth, Yield, and Nutritional Composition of Two Oyster Mushrooms (Pleurotusostreatus and Pleurotus cystidiosus). Mycobiology, 43(4), 423-434. https://doi.org/10.5941/MYCO.2015.43.4.423

Khan, A.M., Khan, S.M., \&Shakir, A.S. (2001). Studies on the cultivation of the oyster mushroom on different substrates. Pak. J. Phytopathol., 13, 140-143.

Khan, M.W., Muhammad, A.A., Khan, N.A., Khan, M.A., Rehman, A., \&Javed, N. (2013). Effect of different levels of lime and $\mathrm{pH}$ on mycelial growth and production efficiency of oyster mushroom (Pleurotusspp.). Pak. J. Bot., 45(1), 297-302.

Krupodorova, T.A., \&Barshteyn, V.Yu. (2012). Alternative substrates for medicinal and edible mushrooms cultivation. Microbiol.Biotechol., 14(1), 47-56 [in Ukrainian].

Nandi, B., \& Mukherjee, R. (2006).Cultivation of P.ostreatus on WeedPlants(ELSEVIERScience Direct, Bioresource Technology-(2006).

Oei, P. (2003). Mushroom Cultivation. Appropriate Technology for Mushroom Growers, $3^{\text {rd }}$ ed. BackhuysPub.,Leiden, Netherlands: 426.

Oseni, T. O., Dube, S. S., Wahome, P. K., Masarirambi, M. T., \& Earnshaw, D. M. (2012). Effect of wheat bran supplement on growth and yield of oyster mushroom (Pleurotusostreatus) on fermented pine sawdust substrate. Experimental Agriculture \& Horticulture, 30-40.

Sanchez, C. (2009). Cultivation of Pleurotus ostreatus and other edible mushrooms. Applied microbiology and biotechnology, 85(5), 1321-37.

Savoie, J.M., Salmones, D., \& Mata, G. (2007). Hydrogen peroxide concentration measured in cultivation substrates during growth and fruiting of the mushrooms. Agaricus bisporus and Pleurotus spp. J. Sci. Food Agric., 87, 1337-1344. 
Shah, Z.A., Ashraf, M., \& Ishtiaq M. (2004). Comparative study on cultivation and yield performance of oyster mushroom (Pleurotusostreatus) on different substrates (wheat straw, leaves, sawdust). Pakistan Journal of Nutrition, 3 (3), 158 - 160.

Shrestha, J. (2019). P-Value: A True Test of Significance in Agricultural Research, Retrieved from https://www.linkedin.com/pulse/p-value-test-significance-agricultural-researchjiban-shrestha/. DOI: http://doi.org/10.5281/zenodo.4030711

Sobhan, A. (2006). Effect of different supplements with different levels to paddy straw substrate on the growth and yield of oyster mushroom.Thesis MSc.Sher-e-Bangla Agricultural University, Dhaka. 26p.

Tan, T.T. (1981). Cotton waste is a fungus (Pleurotus). Good substrate for cultivation of Pleurotus ostreatus the oyster mushroom. Mushroom Science, 11, $705-710$.

Upadhyay, R.C., Verma, R.N., Singh, S.K., \& Yadav, M.C. (2002). Effect of organic nitrogen supplementation in Pleurotusspecies.Mushroom Biology and Mushroom Products.Sa' nchezet al. (Eds.). pp. 225-232. UAEM.ISBN 968-878-105-3.

Viziteu, G. (2004). Oyster mushroom cultivation. Mushroom Growers Handbook.

Wightman, E. K. (1999). Good tree nursery practices; practical guidelines for community nurseries, International Centre for Research in Agroforestry, Majestic printing Works. pp 30 - 42. Accessed from http://outputs.worldagroforestry.org/record/2417/files /B10715. pdf on 24/06/2017.

Zhang, Z.M., \&Obbard, J.P. (2001). Effect of nonionic surfactants on elimination of polycyclic aromatic hydrocarbons (PAHs) in soil slurry by Phanerochaetechrysosporium. J. Chem. Technol. Biotechnol., 76, 423-429. 